\title{
Inflammatory Bowel Disease and Primary Sclerosing Cholangitis
}

\author{
Gulbanu Erkan \\ Ufuk University Faculty of Medicine, Department of İternal Medicine, \\ Division of Gastroenterology \\ Turkey
}

\section{Introduction}

Inflammatory bowel disease (IBD) is a chronic condition which is characterized by recurrent immune-mediated inflammation of the gastrointestinal system. IBD is frequently associated with extraintestinal manifestations (EIM) characterized by involvement of multiple organs. EIM occur in $21 \%$ to $47 \%$ of IBD patients (Navaneethan \& Shen, 2010). While some extraintestinal manifestations are encountered more frequently in Crohn's disease (CD) than in ulcerative colitis (UC), some are encountered equally in CD and UC. While the degree of involvement of the skin, eyes, and joints is parallel to disease activity, hepatobiliary and pulmonary involvement is independent of disease activity and intestinal inflammation (Greenstein AJ, et al., 1996).

Hepatopancreatobiliary (HPB) manifestations are the most frequently encountered EIM in patients with IBD. They can be encountered in various ways:

1. HPB conditions sharing the same pathological mechanisms with IBD (Primary Sclerosing Cholangitis (PSC), small-duct PSC/pericholangitis, and PSC/autoimmune hepatitis overlap, IBD associated acute or chronic idiopathic pancreatitis)

2. HPB conditions that reflect the degree of pathophysiologic damage seen in IBD (Cholelithiasis and portal vein thrombosis)

3. HPB conditions related to side effects of drugs used in treatment of IBD (Drug induced or associated hepatitis, pancreatitis, cirrhosis, Hepatitis B reactivation, hepatosplenic $\mathrm{T}$ cell lymphoma)

4. HPB conditions possibly related to IBD (Autoimmune pancreatitis, IgG4-associated cholangitis, fatty liver, hepatic amiloidosis, granulomatous hepatitis, primary biliary cirrhosis) (Navaneethan \& Shen, 2010)

The various HPB manifestations and their associations are summarized in Tables 1 and 2.

The aim of this chapter is to cover in detail primary sclerosing cholangitis, which is an important and frequently encountered HPB manifestation of ulcerative colitis.

\section{The association of Inflammatory Bowel Disease and Primary Sclerosing Cholangitis}

PSC is a chronic cholestatic hepatobiliary disease that often develops in the setting of IBD and which affects predominantly young to middle-aged patients (Olsson et al., 1991). 


\begin{tabular}{|c|c|}
\hline $\begin{array}{l}\text { HBP manifestations with a possibly } \\
\text { shared pathogenesis and mechanism as } \\
\text { IBD }\end{array}$ & $\begin{array}{l}\text { Primary sclerosing cholangitis(PSC) } \\
\text { Small- duct PSC } \\
\text { Cholangiocarcinoma } \\
\text { Autoimmune hepatitis/PSC overlap } \\
\text { IgG4 associated cholangitis } \\
\text { Acute and chronic idiopathic pancreatitis }\end{array}$ \\
\hline $\begin{array}{l}\text { HPB manifestations parallel the } \\
\text { pathophysiology associated with IBD }\end{array}$ & $\begin{array}{l}\text { Gallstones } \\
\text { Portal vein thrombosis and hepatic abscess }\end{array}$ \\
\hline $\begin{array}{l}\text { HPB manifestations associated with } \\
\text { treatment of IBD }\end{array}$ & $\begin{array}{l}\text { Drug induced hepatitis(azathioprine, 6- } \\
\text { mercaptopurine, methotrexate, cyclosporine, } \\
\text { infliximab) } \\
\text { Reactivation of hepatitis B(infliximab) } \\
\text { Drug induced pancreatitis(azathioprine, 6- } \\
\text { mercaptopurine), Hepatosplenic T-cell } \\
\text { lymphoma }\end{array}$ \\
\hline $\begin{array}{l}\text { HPB manifestations possibly associated } \\
\text { with IBD }\end{array}$ & $\begin{array}{l}\text { Fatty liver } \\
\text { Hepatic amyloidosis } \\
\text { Granulomatous hepatitis } \\
\text { Primary biliary cirrhosis } \\
\text { Autoimmune pancreatitis }\end{array}$ \\
\hline
\end{tabular}

Table 1. Association Between Inflammatory Bowel Disease (IBD) and Hepatopancreatobiliary (HPB) Manifestations. Adapted from Navaneethan \& Shen, 2010

\begin{tabular}{|l|l|l|}
\hline HPB manifestation & Ulcerative Colitis & Crohn's Disease \\
\hline Primary sclerosing cholangitis(PSC) & ++ & + (colonic or ileocolonic) \\
\hline Small duct PSC & ++ & + \\
\hline Cholangiocarcinoma & ++ & + \\
\hline Autoimmunehepatitis/PSC overlap & ++ & + \\
\hline IgG4- associated cholangitis & ++ & + \\
\hline Acute and chronic pancreatitis & + & ++ \\
\hline Gall stones & - & ++ \\
\hline Portal vein thrombosis and hepatic abscess & + & ++ \\
\hline Drug induced hepatitis & ++ & ++ \\
\hline Reactivation of hepatitis B(infliximab) & ++ & ++ \\
\hline Drug induced pancreatitis & + & ++ \\
\hline Hepatosplenic T-cell lymphoma & + - & + \\
\hline Autoimmune pancreatitis & ++ & + \\
\hline Fatty liver & ++ & ++ \\
\hline Hepatic amyloidosis & - & ++ \\
\hline Granulomatous hepatitis & - & ++ \\
\hline Primary biliary cirrhosis & ++ & + \\
\hline
\end{tabular}

Table 2. HPB Manifestations Associated with IBD. Adapted from Navaneethan \& Shen, 2010 
The association of primary sclerosing cholangitis (PSC) and ulcerative colitis (UC) was first reported by Smith and Loe in 1965 (Smith\&Loe, 1965). The incidence of IBD in patients with PSC is $25-30 \%$. Increasing awareness of association of PSC and UC led to more widespread use of endoscopic retrograde cholangiopancreatography (ERCP) and hence more cases were diagnosed with PSC (Broome \& Bergquist, 2006).

The association of PSC and Crohn's disease, which was first described by Atkinson and Carroll in 1964 (Atkinson \& Carroll, 1964), is relatively rare. The incidence of CD in PSC varies between 1.3-14\% (Wiesner \& LaRusso, 1980; Chapman et al., 1980; Rasmussen et al., 1997; McGarity et al., 1991; Faubion et al., 2001; Loftus et al., 2005; Tobias et al., 1983). The most eminent finding is rectal sparing. Colonic stricture and perianastomotic ulcers are relatively rare in this patient group. Patients with PSC and CD almost always have extensive colitis or ileocolitis, but never have isolated ileitis (Broome \& Bergquist, 2006).

About $85-90 \%$ of patients with PSC and IBD are comprised of UC patients and the remainder are comprised of patients with Crohn's colitis or Crohn's ileocolitis (Olsson et al., 1991).

IBD can be diagnosed at any time throughout the course of PSC, and PSC can develop at any time throughout the course of IBD (Fausa et al., 1991; Broome et al., 1990). However, IBD is often diagnosed many years before the diagnosis of PSC. PSC can occur many years after proctocolectomy for colitis; IBD can be diagnosed many years after liver transplantation for advanced PSC ( Fausa et al., 1991; Wiesner \& LaRusso, 1980; Aadland et al., 1987; Chapman et al., 1980; Riley et al., 1997) . As IBD and PSC can be asymptomatic, the time of diagnosis depends on the diagnostic alertness of the physician (Broome \& Bergquist, 2006).

PSC has a variable natural course. Nevertheless, PSC is typically characterized by progressive inflammation, obliterative fibrosis, damage to the intrahepatic and extrahepatic biliary tree and eventually biliary fibrosis, cirrhosis and finally liver failure. PSC is often diagnosed between the $3^{\text {rd }}$ and $5^{\text {th }}$ decades and male to female gender ratio is 2:1 (Chapman et al., 1980; Lee \& Kaplan, 1995; Navaneethan \& Shen, 2010). Freeman et al. observed that patients with PSC had more extensive endoscopic and histological inflammation of the afferent limb who had restorative proctocolectomy with ileal pouch-anal anastomosis (IPAA) for UC than those with no concurrent PSC (Freeman et al., 2008).

A report from Mayo Clinic has identified characteristic clinical, endoscopic, and histological findings in IBD accompanied by PSC as quiescent colitis, substantial preclinical phase, pancolitis, rectal sparing, backwash ileitis, pouchitis, and colorectal dysplasia/carcinoma (Loftus et al., 2005) (Table 3).

\begin{tabular}{|l|}
\hline Clinical, Endoscopic, and Histological Findings that Characterize IBD-PSC \\
\hline Quiescent colitis \\
Substantial preclinical phase \\
Pancolitis \\
Rectal sparing \\
Backwash ileitis \\
Pouchitis \\
Colorectal dysplasia/carcinoma \\
\hline
\end{tabular}

Table 3. Clinical, Endoscopic, and Histological Findings that Characterize IBD-PSC. Adapted from Broome \& Bergquist, 2006 


\subsection{Prevalence of IBD in patients with PSC}

The prevalence of UC in patients with PSC varies from country to country in the range of 21$80 \%$ (Takikawa \& Manabe, 1997; Bergquist A et al., 2002). The prevalence of PSC in patients with Crohn's disease varies between 1.4-3.4\% (Rasmussen et al., 1997; Schrumpf et al., 1980; Shepherd et al., 1983). Colitis in PSC is often quiescent or mild. Therefore, all patients with PSC should undergo colonoscopy and multiple biopsies should be taken to estimate the true prevalence (Broome \& Bergquist, 2006). An algorithm for screening for IBD in patients with PSC is given in Figure 1.



Fig. 1. Screening for IBD in patients with PSC.

Adapted from Navaneethan U, Shen B, 2010, and Broome U, Bergquist A, 2006

\subsection{Prevalence of PSC in patients with IBD}

The prevalence of PSC in patients with IBD and persistently abnormal liver function tests is 2.4-7.5\% (Olson R, et al., 1991; Aadland E et al., 1987). PSC prevalence is $5.5 \%$ in patients with substantial colitis, and $0.5 \%$ in patients with distal colitis (Olsson et al., 1991). 1.3 to $14 \%$ of patients with Crohn's disease have PSC (Wiesner \&LaRusso 1980; Chapman et al., 1980; Rasmussen et al 1997; McGarity et al., 1991; Faubion et al., 2001; Loftus et al., 2005).

PSC can present as an asymptomatic disease characterized by mild increases in aminotransferases, episodes of normal liver function tests can also occur. The frequency of liver function test screening is decisive in determining the prevalence of this disease. However, there may also be liver enzyme elevations due to autoimmune hepatitis, fatty liver, colonic disease activation, total parenteral nutrition and steroid use (Loftus et al., 1997; Broome et al., 1994). Therefore, liver function tests at presentation may be misguiding. Ideally, liver function tests must be assessed when the colonic disease is in the inactive phase (Broome \& Bergquist, 2006). An algorithm for PSC screening in a patient with IBD is presented below in Figure 2.

Enlargement of perihepatic lymph nodes is a common finding in PSC (Outwater et al., 1992). The presence of enlarged perihepatic lymph nodes in a patient with UC should alert the 
clinician for PSC. A prospective study by Hirche et al that involved 310 IBD patients showed that the detection of enlarged perihepatic lymph nodes by ultrasonography (US) was a better predictor of PSC when compared to serum parameters alone (Hirche et al., 2004).

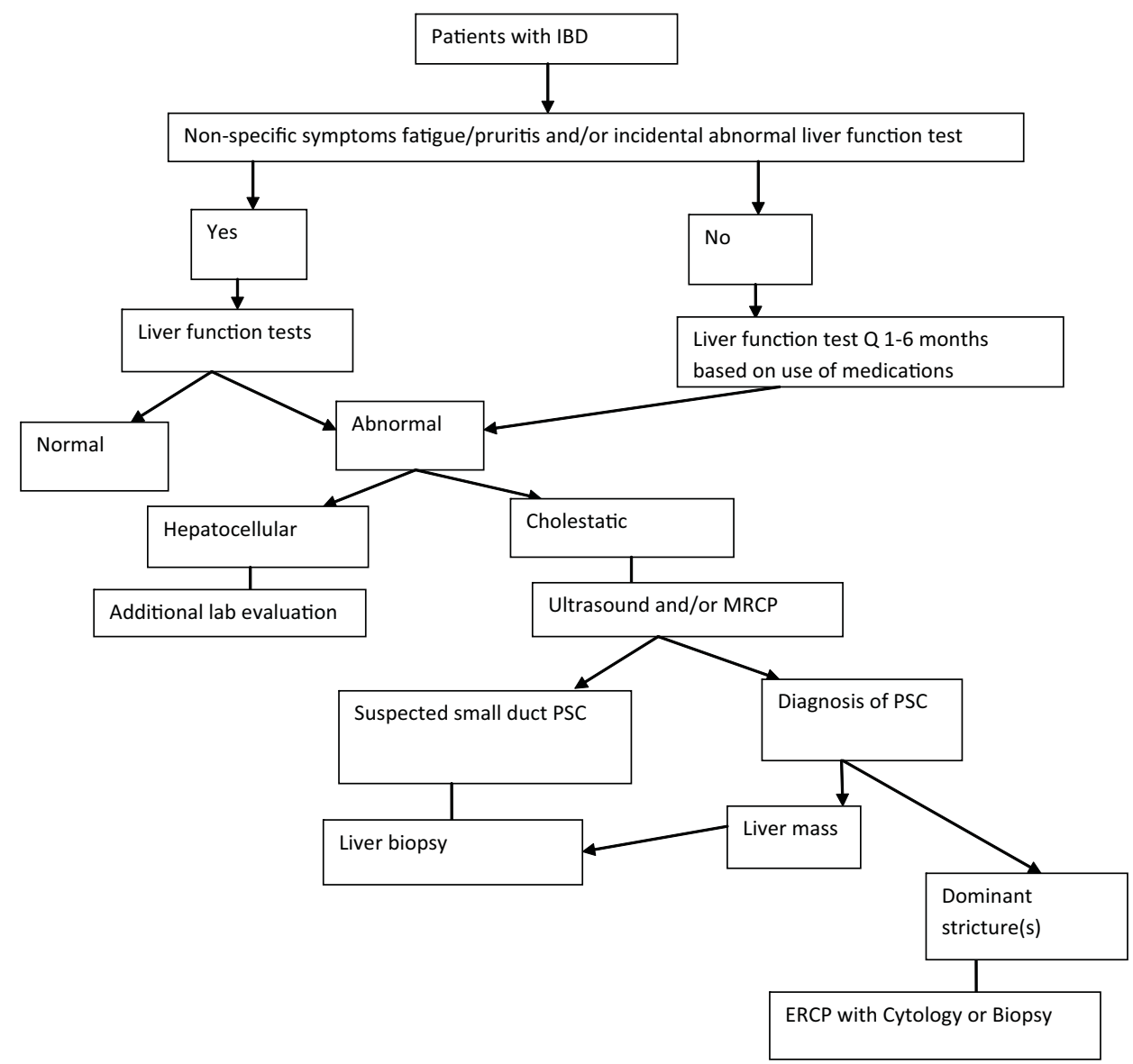

Fig. 2. Screening for PSC in patients with IBD. Adapted from Navaneethan \& Shen, 2010

Rabinowitz et al., who investigated patients with advanced PSC, found that patients with PSC and UC are predominantly male and the first presentation is often mild liver enzyme elevation. Bile duct involvement is different among patients with PSC plus UC and those with PSC only. While the prevalence of combined intrahepatic and extrahepatic bile duct strictures is $82 \%$ in patients with PSC and UC, it is $46 \%$ in those with only PSC. Isolated extrahepatic duct involvement is 38\% in PSC, and 7\% in those with PSC and UC (Rabinovitz et al., 1990). Among 305 Swedish PSC patients, no difference between patients with and without IBD could be found (Broome et al., 1996). Currently, we do not have enough data to arrive at a conclusion that PSC in patients without IBD is an entity different from PSC that accompanies IBD.

Rectal sparing and backwash ileitis are more common in patients with UC and PSC (Loftus et al., 2005). As rectal sparing is common in these patients, rectosigmoidoscopy is not 
adequate in demonstrating the association of UC and PSC, a colonoscopy is often recommended (Faubion et al., 2001; Perdigoto et al., 1991).

The clinical course of colitis is variable in patients who undergo OLT for PSC. MacLean et al have reported clinical healing in one third of patients, unchanged clinical course in one third, and worsening in the last one third (MacLean et al., 2003).

In UC patients operated on with an ileal pouch-anal anastomosis, nonspecific inflammation of the pouch (pouchitis) is the most frequent long-term complication. Chronic pouchitis is more common in patients with PSC and UC when compared to those with UC only $(60 \%$ vs $15 \%)($ Penna et al., 1996). Pouchitis continues to occur after OLT in patients with PSC (Zins BJ et al., 1995).

\section{Impact of coexisting PSC on the disease behavior and course of IBD}

Patients with PSC and IBD have a different clinical course when compared to IBD patients not complicated with PSC, and this patient group has been defined by the Mayo clinic as a different clinical entity (Loftus et al., 2005). While UC can be diagnosed many years after PSC diagnosis and even after orthotopic liver transplantation(OLT), a patient with UC, who had a proctocolectomy or not, can be diagnosed with PSC many years later (Joo et al.,2009).

Patients with UC and PSC more frequently experience rectal sparing, backwash ileitis, pancolitis, colorectal neoplasia when compared to patients with UC alone, and their prognosis is worse ( Faubion et al., 2001; Loftus et al., 2005; Loftus et al., 1997; Penna et al.; 1996; Heuschen et al., 2001; Lundkvist \& Broome, 1997; Broome et al., 1995; Soetikno et al., 2002). However, there are studies reporting different results. A recent case -control study found no difference between patients with PSC plus IBD and IBD alone in terms of rectal sparing. The same investigators found similar backwash ileitis prevalences in the PSC plus UC group and the UC alone group (Joo et al., 2009).

It was suggested that patients with PSC and UC may more likely run a quiescent course of colitis than UC patients without coexistent PSC. PSC-UC patients have colitis with a lower histopathological grade of inflammation (Joo et al.,2009). In a study from Sweden that included 76 patients with PSC, 7 of 11 asymptomatic patients had a histopathological diagnosis of IBD, and 2 of these 7 patients had colonic dysplasia. In the follow-up, these 2 patients died before developing any IBD symptoms while 3 patients developed IBD symptoms (Broome et al.,1995).

A colonoscopy must be performed at the time of PSC diagnosis for IBD screening (Faubion et al., 2001). Currently, there is no guideline about the necessity and frequency of colonoscopic screening in asymptomatic patients with a normal baseline screening colonoscopy. However, patients with PSC and UC/Crohn's colitis should undergo annual colonoscopy (Kornbluth \& Sachar,1997).

The risk of pouchitis after restorative proctocolectomy is higher in patients with PSC and UC when compared to patients with UC alone ( Faubion et al.,2001; Loftus et al., 2005; Penna et al., 1996) . On the other hand, there is no correlation between the severity of liver disease and the risk of pouchitis (Penna et al., 1996).

While there are conflicting reports in the literature, it is generally agreed upon that the risk of IBD-associated colonic dysplasia is increased in the presence of PSC. In a meta-analysis, the presence of PSC was an independent risk factor for colorectal dysplasia/cancer in UC patients with an odds ratio of 4.79 (Soetikno et al.,2002). Screening colonoscopy is associated with a survival benefit in patients with PSC and UC or Crohn's colitis (Rutter et 
al., 2004), and a yearly colonoscopy is recommended beginning from the time of PSC diagnosis (Kornbluth \& Sachar,1997). The risk for dyplasia seems to remain high after colectomy in patients with PSC and UC (Ståhlberg et al.,2003). According to histological and flow cytometry studies, atrophy in the pouch mucosa, dysplasia, and DNA aneuploidia are more common in PSC plus UC patients with IPAA when compared to patients with UC only with IPAA (Ståhlberg et al.,2003).

\section{The impact of coexisting IBD on the disease behavior and course of PSC}

In a liver biopsy study that compared PSC patients with and without accompanying IBD no difference was found in terms of liver histopathology (Ludwig et al.,1981). Two other studies were unable to define any specific clinical or radiological criteria to distinguish patients with UC plus PSC from those with PSC alone (Broome et al., 1996; MacCarty et al., 1985). On the other hand, Rabinovitz et al showed that the first sign of liver disease was often liver enzyme abnormality in PSC accompanied by IBD. In contrast, liver disease more often presented with jaundice, pruritus, and fatigue in patients with PSC alone (Rabinowitz et al., 1990).

\section{Pathogenesis}

As IBD tends to coexist with other autoimmune diseases such as Type I diabetes mellitus and Graves' disease (Saarinen S et al., 2000), genetic and immunological mechanisms have been extensively studied (Navaneethan \& Shen, 2010). HLA-B8, HLA-DRB1*0301(DR3), HLA-DR3*0101(DRw52a), and HLA-DRB1*0401(DR4) are among genetic variants that are associated with susceptibility to IBD (Farrant et al., 1992; Olerup et al., 1995). Many antibodies have been detected in PSC patients with varying prevalences, including antinuclear antibodies (24-53\%), smooth muscle antibodies (13-20\%), anti-perinuclear cytoplasmic antibody ( 65-88\%) (Mulder et al., 1993; Bansi et al., 1996; Terjung \& Spengler, 2005; Terjung et al., 2000). However, in contrast to other autoimmune diseases, PSC is more frequently encountered in male subjects, and it does not respond to immunosuppressive therapy (O'Mahony \& Vierling, 2006). One hypothesis that aims to explain the increased incidence of PSC in IBD patients postulates that the transportation of bacterial endotoxins from the inflamed colonic mucosa to the liver via the portal circulation stimulates the Kupffer cells (Fausa et al., 1991; Aoki et al., 2005). However, another study showed that there is no evidence of altered intestinal permeability or bacterial overgrowth in PSC patients (Björnsson et al.,2000). Other factors that are suspected to play a role in pathogenesis are ANCA autoantigen Beta-tubulin isotype 5 (TBB5) that shares epitopes with microbial antigens and human autoantigens (Erickson,1995) and leaky gut (Terjung \& Spengler,2009).

\section{Diagnosis}

Most PSC patients are asymptomatic at the time of diagnosis. Fatigue, pruritus, jaundice, abdominal pain, and weight loss are the presenting symptoms in $10-15 \%$ of the patients (Tischendorff et al., 2007; Wiesner et al., 1989). A cholestatic pattern of abnormal liver function tests in the form of elevation in alkaline phosphatase is a biochemical feature for PSC (Rasmussen HH et al., 1997; Talwalkar \& Lindor, 2005).The most frequent cause of persistent liver enzyme elevation in a patient with IBD is PSC (Heikius et al., 1997). PSC is also the most frequent cause of persistent liver enzyme elevation in an IBD patient with 
proctocolectomy (Navaneethan et al.,2009). Various antibodies may be detected with varying prevalences (antinuclear antibodies $24-53 \%$, antismooth muscle antibodies $13-20 \%$, p-ANCA 65-88\%). Nevertheless, the role of these antibodies in diagnosis and discrimination between isolated PSC and PSC accompanied by IBD remains unclear (Mulder et al., 1993; Bansi et al., 1996; Terjung \& Spengler, 2005; Terjung et al., 2000).

Diffuse, multifocal strictures involving the medium- sized intrahepatic and/or medium or large- sized extrahepatic ducts demonstrated by cholangiography constitutes the gold standard in the diagnosis of PSC (MacCarty et al.,1983) (Pictures 1 and 2). ERCP may be used both for diagnostic and therapeutic purposes, but is associated with procedure-related complications such as cholangitis and pancreatitis (Moreno \& Gores, 2006). Magnetic Resonance Cholangiopancreatography (MRCP) is a non-invasive alternative tool for PSC diagnosis. MRCP has a sensitivity of $80-91 \%$, specifity of $85-99 \%$, and diagnostic accuracy of 83-93\% for diagnosis of PSC, all of which are slightly lower than those of ERCP (Fulcher et al., 2000; Angulo et al., 2000; Moff et al., 2006; Berstad et al., 2006; Textor et al., 2002).

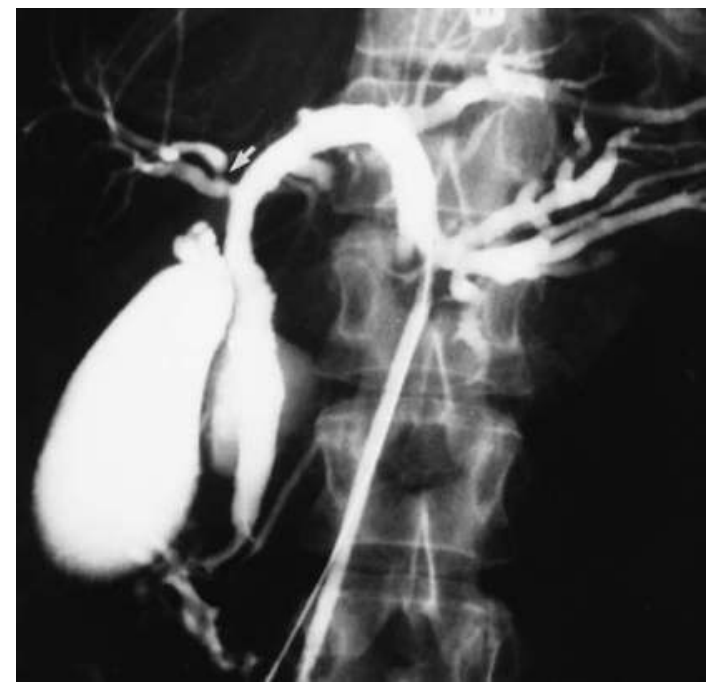

Picture 1. Percutaneus cholangiogram displaying early PSC in a 45-year-old man with ulcerative colitis and elevated results of liver function tests. (Vitellas et al., 2000)

Liver biopsy is useful for the diagnosis of small-duct PSC or pericholangitis in IBD patients with cholestatic enzyme elevation and a normal cholangiogram (Burak et al., 2003). US examination of the liver may be used for screening in patients with liver enzyme elevation. The demonstration of dilated bile ducts by US may guide the clinician for further evaluations such as ERCP or liver biopsy. Nevertheless, there is no published data about the value of abdominal US for screening purposes in PSC (Navaneethan U, Shen B, 2010).

Another clinical scenario that may be encountered throughout the clinical course of PSC is cholangiocarcinoma ( Picture 3) .Current imaging methods have limited capability in the early diagnosis of cholangiocarcinoma and most patients are diagnosed at advanced stages of the disease. Computerized tomography (CT) and magnetic resonance imaging (MRI) have higher sensitivity than US, but US examination may provide better accuracy than CT and MRI in distinguishing cholangiocarcinoma from underlying PSC (Charatcharoenwitthaya et 
al., 2008). When a mass lesion is detected by US ,CT or MRI may be performed to assess the extent of the mass.

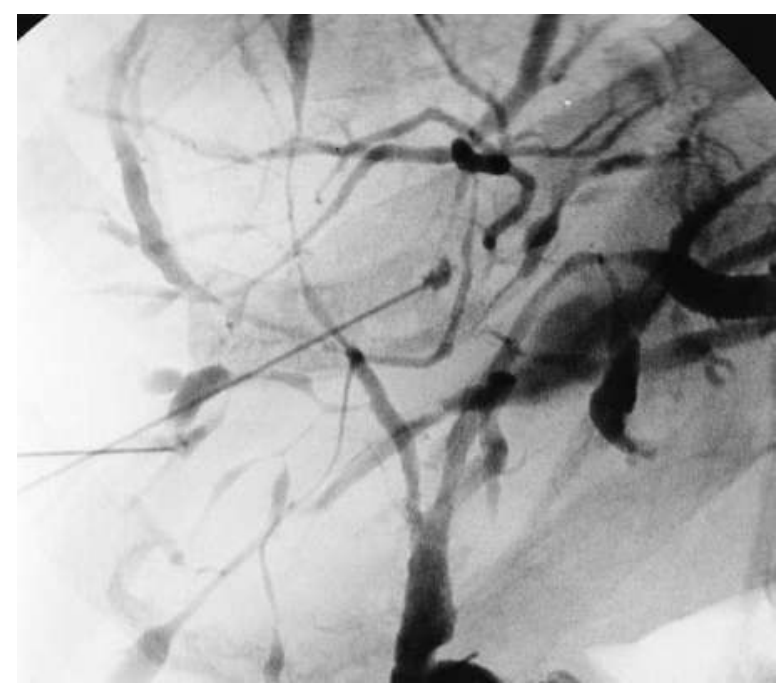

Picture 2. Percutaneus cholangiogram displaying PSC in a 67-year-old man with ulcerative colitis and jaundice. (Vitellas et al., 2000)



Picture 3. MRCP image of cholangiocarcinoma in a 29-year-old man with ulcerative colitis and primary sclerosing cholangitis who presented with jaundice and abdominal pain.

(Vitellas et al., 2000) 
ERCP with brush cytology or CT/ US guided biopsy of the mass may be required to accurately establish the diagnosis. ERCP is especially useful for the final diagnosis of cholangiocarcinoma, as it provides opportunities such as brush cytology and obtaining a biopsy sample (Charatcharoenwitthaya et al.,2008). The application of advanced cytological techniques such as digital imaging analysis (DIA) and fluorescent in situ hybridization (FISH) in brush cytology and biopsy samples obtained by ERCP may further facilitate the early diagnosis of cholangiocarcinoma (Moreno \& Gores, 2006; Rea et al., 2005; Parsi et al., 2008). The sensitivity of combined use of cytology, FISH and DIA is 50-64\%, spesicifity and positive predictive value is $100 \%$ (Charatcharoenwitthaya et al.,2008 ). The National Institutes of Health consensus statement on the role of diagnostic and therapeutic ERCP described the role of ERCP in the diagnosis of biliary cancers in patients with PSC (Cohen et al.,2002 ). It is not clear whether a different surveilliance program is needed in case PSC is accompanied by IBD. An algorithm for cholangiocarcinoma screening in patients with IBD and PSC is given below (Figure 3). The advantages and disadvantages of diagnostic modalities are summarized in Table 4.



Fig. 3. Surveilliance of cholangiocarcinoma in patients with IBD-PSC (Adapted from Charatcharoenwitthaya P and Lindor KD, 2007) 


\begin{tabular}{|l|l|l|}
\hline Diagnostic modality & Advantages & Disadvantages \\
\hline $\begin{array}{l}\text { Endoscopic retrograde } \\
\text { cholangiopancreatography(ERCP) }\end{array}$ & $\begin{array}{l}\text {-Can be both diagnostic } \\
\text { and therapeutic } \\
\text { Gold standart for } \\
\text { diagnosis of PSC }\end{array}$ & $\begin{array}{l}\text {-Complications, } \\
\text { including post-ERCP } \\
\text { pancreatitis. } \\
\text {-Procedure associated } \\
\text { cholangitis }\end{array}$ \\
\hline $\begin{array}{l}\text { Magnetic resonance retrograde } \\
\text { cholangiopancreatography } \\
(\mathrm{MRCP})\end{array}$ & $\begin{array}{l}\text {-Visualizing bile ducts } \\
\text { proximal to a complete } \\
\text { bile duct obstruction } \\
\text {-Useful in patients with } \\
\text { gastric bypass or biliary- } \\
\text { enteric anastomosis } \\
\text { without radiation } \\
\text { exposure }\end{array}$ & $\begin{array}{l}\text {-Purely diagnostic } \\
\text {-PSC limited to the } \\
\text { peripheral ducts } \\
\text {-Sensitivity and } \\
\text { specificity slightly } \\
\text { inferior to ERCP }\end{array}$ \\
\hline Liver biopsy & $\begin{array}{l}\text {-Diagnosis of small duct } \\
\text { PSC in suspected } \\
\text { patients with a normal } \\
\text { cholangiography }\end{array}$ & $\begin{array}{l}\text {-Patchy nature of PSC } \\
\text { which leads to } \\
\text { sampling error }\end{array}$ \\
\hline Abdominal ultrasound & $\begin{array}{l}\text { Screening for biliary } \\
\text { ductal dilatation }\end{array}$ & $\begin{array}{l}\text { Insensitive for } \\
\text { diagnosis of PSC }\end{array}$ \\
\hline
\end{tabular}

Table 4. Diagnostic modalities in primary sclerosing cholangitis (Adapted from Navaneethan \& Shen 2010)

\section{Natural history}

Both symptomatic and asymptomatic PSC patients have decreased survival rates when compared to healthy population (Porayko et al., 1990). Median survival from time of diagnosis to death or liver transplantation was reported as 10 years (Farrant et al., 1991).

In a Dutch cohort, transplantation free survival was 18 years on average (Ponsioen et al.,2002 ). PSC patients are prone to end stage liver disease complications such as esophageal varices, ascites, and hepatic encephalopathy. There are no guidelines on timing of screening for esophageal varices in PSC with or without IBD except for patients with cirrhosis. Because of the patchy nature of PSC, liver biopsy is limited by sampling error. Thus, noninvasive diagnostic methods were explored. A platelet count less than $150000 / \mathrm{mm}^{3}$ may be a marker for the presence of esophageal varices (Zein et al.,2004). The composite Mayo Risk Score based on age, serum bilirubin, albumin, aspartate aminotransferase and variceal bleeding has been used to assess disease progression and prognosis (Kim et al., 2000).

Cholangiocarcinoma is another complication of PSC and annual incidence is $0.6 \%$ $1 \%$ (Bergquist el al., 2007). It can develop at any stage of PSC, it can present as an intraductal tumor in the biliary system or rarely as a hepatic mass (Fevery et al.,2007). The risks of colorectal cancer and pancreatic cancer are also increased in patients with PSC when compared to the general population (Kim et al., 2000 ).

\section{Management}

The presence of accompanying IBD does not change the therapeutic approach in patients with PSC. Currently, there is no treatment option capable of halting progression to PSC or 
modifying the natural course of the disease. Ursodeoxycholic acid (UDCA) is widely used for the treatment of PSC. A randomized trial which tested a UDCA dose of 13-15 $\mathrm{mg} / \mathrm{kg} /$ day showed normalization in liver enzyme levels, however, there was no improvement of liver histology or liver transplant free survival (Lindor,1997). In another randomized trial that included 219 patients, a higher dosage of UDCA treatment (17-23 $\mathrm{mg} / \mathrm{kg} /$ day) did not result in any benefit in terms of mortality, need for OLT, or cholangiocarcinoma risk (Olsson, 2005). A pilot study reported that a very high dosage of UDCA (28-30 mg/kg/day) might improve survival (Cullen et al., 2008) ,however, a large multicenter randomized controlled trial was terminated prematurely due to side effects in the treatment arm (Lindor et al., 2009).

UDCA treatment can prevent colonic neoplasia in PSC-IBD patients (Tung et al., 2001). On the other hand, high dose UDCA treatment was reported to increase the risk of colon cancer in PSC-UC patients (Eaton et al., 2011).

The treatment of choice in end stage PSC or cholangiocarcinoma-PSC is OLT. The 5 and 10 year survival rates in PSC patients are 85\% and 70\%, repectively (Rea et al., 2005 and Graziadei et al., 1999a). On the other hand, the rate of PSC recurrence in the transplanted liver is 20\%-25\% (Graziadei et al., 1999b).

Small-duct PSC: This entity was previously termed pericholangitis. These patients have biochemical and histopathological features compatible with PSC despite normal cholangiograms (Wee et al., 1985). The Mayo Clinic's criteria for the diagnosis of small-duct PSC mandates the presence of coexisting IBD (Angulo et al., 2002). On the other hand, European criteria for small duct PSC does not include the presence of IBD (Björnsson et al., 2002 and, Broome et al., 2002). Initial studies with limited follow-up suggested that patients with small-duct PSC have a better prognosis than those with its large-duct counterpart (Angulo P et al., 2002; Björnsson et al., 2002 and, Broome et al., 2002). A large multicenter study with a longer follow-up period showed that the incidence of IBD is $80 \%$ in patients with small-duct PSC. Accompanying IBD was UC in 78\%, Crohn's colitis in 21\%, and collagenous colitis in one patient (Björnsson et al., 2008).

The presence of IBD does not seem to have an effect on the course of liver disease in patients with small-duct PSC. $12-23 \%$ of patients with small-duct PSC progress to large-duct PSC. Cholangiocarcinoma developing in the setting of isolated small-duct PSC has never been reported in the literature, unless it progresses to large-duct PSC (Björnsson et al., 2008). In some patients, OLT may be necessary because of progressive disease and disease recurrence may be encountered in the transplanted liver. If the alkalene phosphatase level is elevated, cholangiogram is normal, and other hepatobiliary diseases are ruled out in an IBD patient, liver biopsy may be required to rule out small-duct PSC (Navaneethan \& Shen, 2010).

\section{Disease course of IBD following liver transplantation for PSC}

OLT for PSC or PSC-associated cholangiocarcinoma may affect the clinical course of UC, as corticosteriods and other immunosuppressive agents used following OLT may theoretically improve coexisting UC. However, while some studies report alleviation of UC-associated symptoms after OLT (Saldeen et al., 1999 and Befeler et al., 1998), some studies report exacerbation of symptoms after OLT (Riley et al., 1997; Papatheodoridis et al., 1998 and Verdonk et al., 2006).

The effect of OLT on the natural course of ileal pouch in UC patients undergoing restorative proctocolectomy seems to be minor. In some case series, OLT and subsequent 
immunosuppressive therapy did not have a significant effect on the severity of pouchitis (Zins BJ et al.,1995). In a recent study investigating the modification of chronic pouchitis course by PSC and/or OLT performed for PSC, 14 of 32 patients who underwent both IPAA and OLT for PSC experienced chronic pouchitis and in 8 patients PSC recurred, with 4 of them requiring retransplantation (Mathis et al., 2008). Large scale studies are needed to clarify the disease nature of pouchitis and the interaction of it with OLT and OLT related procedures.

\section{Course of liver disease following IPAA}

IPAA does not appear to affect the disease course of PSC and PSC appears to follow an independent disease course in spite of proctocolectomy (Poritz \& Koltun, 2003). In a study of 214 patients with UC undergoing IPAA including 13 (6.1\%) with PSC, 4 patients with PSC showed clinical progression, while none of these patients with minor histological changes progressed with a follow-up over 9 years (Mikkola et al., 1995). In a study of PSC in 68 patients with UC with 30 having follow-up examinations, the staging of PSC on liver biopsy after IPAA showed disease progression in $4(13 \%)$, regression in $15(50 \%)$, and stable in 11 $(37 \%)$ from baseline liver histology at the time of proctocolectomy. Six of the 68 patients $(8.8 \%)$ developed cholangiocarcinoma. The progression of PSC in patients with minor ductal changes appeared to be uncommon after IPAA surgery (Lepistö et al., 2009).

\section{Colorectal Dysplasia and carcinoma in patients with Ulcerative Colitis and Primary Sclerosing Cholangitis}

It is well-known that the risk of developing colorectal carcinoma is increased in patients with UC. Disease duration and extensive colitis are two major risk factors for this serious complication. The mechanism of developing malignancy in UC is not fully understood. Recent studies have shown that family history of sporadic colorectal carcinoma (Askling et al., 2001), presence of active inflammation in the mucosa (Rutter et al., 2004), and presence of PSC increase the risk of dysplasia and colorectal carcinoma in patients with UC (Kornfeld et al., 1997; Brentnall et al., 1996). A study from Sweden has shown that the incidence of colorectal dysplasia and carcinoma in patients with UC and PSC at 10, 20, and 25 years is $9 \%, 31 \%$ and $50 \%$ respectively (Broome et al., 1995). A meta-analysis of 11 studies has shown that the presence of PSC is an independent risk factor for colorectal dysplasia/carcinoma in patients with UC (Soetikno et al.,2002).

The incidence of colorectal dysplasia/cancer is high after orthotopic liver transplantation (OLT) in patients with UC and PSC (Bleday et al., 1993; Higashi et al., 1990). The risk of developing colorectal carcinoma increases over time after OLT. Vera et al. have identified three risk factors for developing colorectal carcinoma after OLT; colitis duration of more than 10 years, pancolitis, and dysplasia after OLT (Vera et al., 2003). A yearly colonoscopy is adequate in patients with PSC and UC, beginning from the time of PSC diagnosis (Broome \& Bergquist, 2006).

\section{References}

Aadland E, Schrumpf E, Fausa O, Elgjo K, Heilo A, Aakhus T, Gjone E. Primary sclerosing cholangitis: a long-term follow-up study. Scand J Gastroenterol. 1987 Aug;22(6):655-64. 
Angulo P, Maor-Kendler Y, Lindor KD.Small-duct primary sclerosing cholangitis: a longterm follow-up study. Hepatology. 2002 Jun;35(6):1494-500.

Angulo P, Pearce DH, Johnson CD, Henry JJ, LaRusso NF, Petersen BT, Lindor KD. Magnetic resonance cholangiography in patients with biliary disease: its role in primary sclerosing cholangitis.J Hepatol. 2000;33(4):520-7.

Aoki CA, Bowlus CL, Gershwin ME.The immunobiology of primary sclerosing cholangitis. Autoimmun Rev. 2005;4(3):137-43.

Askling J, Dickman PW, Karlén P, Broström O, Lapidus A, Löfberg R, Ekbom A. Family history as a risk factor for colorectal cancer in inflammatory bowel disease. Gastroenterology. 2001 May;120(6):1356-62.

Atkinson AJ, Carroll WW. Sclerosing cholangitis, association with regional enteritis. JAMA 1964;188:183-4.

Bansi DS, Fleming KA, Chapman RW. Importance of antineutrophil cytoplasmic antibodies in primary sclerosing cholangitis and ulcerative colitis: prevalence, titre, and IgG subclass. Gut. 1996 Mar;38(3):384-9.

Befeler AS, Lissoos TW, Schiano TD, Conjeevaram H, Dasgupta KA, Millis JM, Newell KA, Thistlethwaite JR, Baker AL. Clinical course and management of inflammatory bowel disease after liver transplantation.Transplantation. 1998 Feb 15;65(3):393-6.

Bergquist A, Ekbom A, Olsson R, Kornfeldt D, Lööf L, Danielsson A, Hultcrantz R, Lindgren S, Prytz H, Sandberg-Gertzén H, Almer S, Granath F, Broomé U. Hepatic and extrahepatic malignancies in primary sclerosing cholangitis. J Hepatol. 2002 Mar;36(3):321-7.

Berstad AE, Aabakken L, Smith HJ, Aasen S, Boberg KM, Schrumpf E. Diagnostic accuracy of magnetic resonance and endoscopic retrograde cholangiography in primary sclerosing cholangitis. Clin Gastroenterol Hepatol. 2006;4(4):514-20.

Björnsson E, Boberg KM, Cullen S, Fleming K, Clausen OP, Fausa O, Schrumpf E, Chapman RW.Patients with small duct primary sclerosing cholangitis have a favourable long term prognosis.Gut. 2002 Nov;51(5):731-5.

Björnsson E, Olsson R, Bergquist A, Lindgren S, Braden B, Chapman RW, Boberg KM, Angulo $\mathrm{P}$. The natural history of small-duct primary sclerosing cholangitis. Gastroenterology. 2008 Apr;134(4):975-80.

Björnsson ES, Kilander AF, Olsson RG. Bile duct bacterial isolates in primary sclerosing cholangitis and certain other forms of cholestasis--a study of bile cultures from ERCP. Hepatogastroenterology. 2000;47(36):1504-8.

Bleday R, Lee E, Jessurun J, Heine J, Wong WD. Increased risk of early colorectal neoplasms after hepatic transplant in patients with inflammatory bowel disease. Dis Colon Rectum. 1993 Oct;36(10):908-12.

Brentnall TA, Haggitt RC, Rabinovitch PS, Kimmey MB, Bronner MP, Levine DS, Kowdley KV, Stevens AC, Crispin DA, Emond M, Rubin CE.Risk and natural history of colonic neoplasia in patients with primary sclerosing cholangitis and ulcerative colitis. Gastroenterology. 1996 Feb;110(2):331-8.

Broome U, Bergquist A. Primary sclerosing cholangitis, inflammatory bowel disease, and colon cancer. Semin Liver Dis 2006;26(1):31-41.

Broome U, Glaumann H, Hellers G, Nilsson B, Sörstad J, Hultcrantz R. Liver disease in ulcerative colitis: an epidemiological and follow up study in the county of Stockholm. Gut. 1994 Jan;35(1):84-9. 
Broomé U, Glaumann H, Lindstöm E, Lööf L, Almer S, Prytz H, Sandberg-Gertzén H, Lindgren S, Fork FT, Järnerot G, Olsson R. Natural history and outcome in 32 Swedish patients with small duct primary sclerosing cholangitis (PSC). J Hepatol. 2002 May;36(5):586-9.

Broomé U, Löfberg R, Lundqvist K, Veress B. Subclinical time span of inflammatory bowel disease in patients with primary sclerosing cholangitis. Dis Colon Rectum. 1995 ;38(12):1301-

Broomé U, Löfberg R, Veress B, Eriksson LS. Primary sclerosing cholangitis and ulcerative colitis: evidence for increased neoplastic potential.Hepatology. 1995 Nov;22(5):1404-8.

Broomé U, Olsson R, Lööf L, Bodemar G, Hultcrantz R, Danielsson A, Prytz H, SandbergGertzén H, Wallerstedt S, Lindberg G. Natural history and prognostic factors in 305 Swedish patients with primary sclerosing cholangitis. Gut. 1996 ;38(4):610-5.

Broomé U, Glaumann H, Hultcrantz R. Liver histology and follow up of 68 patients with ulcerative colitis and normal liver function tests. Gut 1990;31:468-71.

Burak KW, Angulo P, Lindor KD. Is there a role for liver biopsy in primary sclerosing cholangitis? Am J Gastroenterol. 2003;98(5):1155-8.

Chapman RW, Arborgh BA, Rhodes JM, Summerfield JA, Dick R, Scheuer PJ, Sherlock S. Primary sclerosing cholangitis: a review of its clinical features, cholangiography, and hepatic histology. Gut. 1980;21(10):870-7.

Charatcharoenwitthaya P, Enders FB, Halling KC, Lindor KD. Utility of serum tumor markers, imaging, and biliary cytology for detecting cholangiocarcinoma in primary sclerosing cholangitis.Hepatology. 2008;48(4):1106-17.

Cohen S, Bacon BR, Berlin JA, Fleischer D, Hecht GA, Loehrer PJ Sr, McNair AE Jr, Mulholland M, Norton NJ, Rabeneck L, Ransohoff DF, Sonnenberg A, Vannier MW.National Institutes of Health State-of-the-Science Conference Statement: ERCP for diagnosis and therapy, January 14-16, 2002. Gastrointest Endosc. 2002 ;56(6):803-9.

Cullen SN, Rust C, Fleming K, Edwards C, Beuers U, Chapman RW. High dose ursodeoxycholic acid for the treatment of primary sclerosing cholangitis is safe and effective.J Hepatol. 2008 May;48(5):792-800.

Eaton JE, Silveira MG, Pardi DS, Sinakos E, Kowdley KV, Luketic VA, Harrison ME, McCashland T, Befeler AS, Harnois D, Jorgensen R, Petz J, Lindor KD. High-Dose Ursodeoxycholic Acid Is Associated With the Development of Colorectal Neoplasia in Patients With Ulcerative Colitis and Primary Sclerosing Cholangitis. Am J Gastroenterol. 2011 May 10 [Epub ahead of print].

Erickson HP. FtsZ, a prokaryotic homolog of tubulin? Cell. 1995 Feb 10;80(3):367-70.

Farrant JM, Doherty DG, Donaldson PT, Vaughan RW, Hayllar KM, Welsh KI, Eddleston AL, Williams R. Amino acid substitutions at position 38 of the DR beta polypeptide confer susceptibility to and protection from primary sclerosing cholangitis. Hepatology. 1992 ;16(2):390-5.

Farrant JM, Hayllar KM, Wilkinson ML, Karani J, Portmann BC, Westaby D, Williams R. Natural history and prognostic variables in primary sclerosing cholangitis. Gastroenterology. $1991 ; 100(6): 1710-7$.

Faubion WA Jr, Loftus EV, Sandborn WJ, Freese DK, Perrault J.Pediatric "PSC-IBD": a descriptive report of associated inflammatory bowel disease among pediatric patients with PSC. J Pediatr Gastroenterol Nutr. 2001;33(3):296-300.

Fausa O, Schrumpf E, Elgjo K. Relationship of inflammatory bowel disease and primary sclerosing cholangitis. Semin Liver Dis. 1991 ;11(1):31-9. 
Fevery J, Verslype C, Lai G, Aerts R, Van Steenbergen W. Incidence, diagnosis, and therapy of cholangiocarcinoma in patients with primary sclerosing cholangitis.Dig Dis Sci. 2007 Nov;52(11):3123-35.

Freeman K, Bennett AE, Lopez R, Shen B. Primary sclerosing cholangitis is associated with endoscopic and histologic backwash ileitis in patients with ileal pouch-anal anastomosis. Gastroenterology. 2008;134(suppl 1):A344.

Fulcher AS, Turner MA, Franklin KJ, Shiffman ML, Sterling RK, Luketic VA, Sanyal AJ. Primary sclerosing cholangitis: evaluation with MR cholangiography-a case-control study. Radiology. 2000;215(1):71-80.

Graziadei IW, Wiesner RH, Batts KP, Marotta PJ, LaRusso NF, Porayko MK, Hay JE, Gores GJ, Charlton MR, Ludwig J, Poterucha JJ, Steers JL, Krom RA. Recurrence of primary sclerosing cholangitis following liver transplantation. Hepatology. 1999 Apr;29(4):1050-6.

Graziadei IW, Wiesner RH, Marotta PJ, Porayko MK, Hay JE, Charlton MR, Poterucha JJ, Rosen CB, Gores GJ, LaRusso NF, Krom RA. Long-term results of patients undergoing liver transplantation for primary sclerosing cholangitis. Hepatology. 1999 Nov;30(5):1121-7.

Greenstein AJ, Janowitz HD, Sachar DB. The extra-intestinal complications of Crohn's disease and ulcerative colitis: a study of 700 patients. Medicine(Baltimore) 1996;55:401-12.

Heikius B, Niemelä S, Lehtola J, Karttunen T, Lähde S. Hepatobiliary and coexisting pancreatic duct abnormalities in patients with inflammatory bowel disease. Scand J Gastroenterol. 1997 Feb;32(2):153-61.

Heuschen UA, Hinz U, Allemeyer EH, Stern J, Lucas M, Autschbach F, Herfarth C, Heuschen G. Backwash ileitis is strongly associated with colorectal carcinoma in ulcerative colitis. Gastroenterology. 2001;120(4):841-7.

Higashi H, Yanaga K, Marsh JW, Tzakis A, Kakizoe S, Starzl TE. Development of colon cancer after liver transplantation for primary sclerosing cholangitis associated with ulcerative colitis. Hepatology. 1990 Mar;11(3):477-80.

Hirche TO, Russler J, Braden B Schuessler G, Zeuzem S, Wehrmann T, Seifert H, Dietrich CF. Sonographic detection of perihepatic lymphadenopathy is an indicator for primary sclerosing cholangitis in patients with inflammatory bowel disease. Int $J$ Colorectal Dis. 2004 Nov;19(6):586-94.

Joo M, Abreu-e Lima P, Farreye F, Smith T, Swaroop P, Gardner L, Lauwers GY, Odze RD. Pathologic features of ulcerative colitis in patients with primary sclerosing cholangitis: a case-control study. Am J Surg Pathol. 2009 Jun;33(6):854-62.

Kornbluth A, Sachar DB. Ulcerative practice guidelines in adults. American College of Gastroenterology, Practice Parameters Committee. Am J Gastroenterol 1997;92:204211.

Kim WR, Therneau TM, Wiesner RH, Poterucha JJ, Benson JT, Malinchoc M, LaRusso NF, Lindor KD, Dickson ER. A revised natural history model for primary sclerosing cholangitis.Mayo Clin Proc. 2000 ;75(7):688-94.

Kornfeld D, Ekbom A, Ihre T. Is there an excess risk for colorectal cancer in patients with ulcerative colitis and concomitant primary sclerosing cholangitis? A population based study. Gut. 1997 Oct;41(4):522-5.

Lee YM, Kaplan MM. Primary sclerosing cholangitis. N Engl J Med. 1995;332:924-33. 
Lepistö A, Kivistö S, Kivisaari L, Arola J, Järvinen HJ. Primary sclerosing cholangitis: outcome of patients undergoing restorative proctocolecetomy for ulcerative colitis. Int J Colorectal Dis. 2009 Oct;24(10):1169-74.

Lindor KD, Kowdley KV, Luketic VA, Harrison ME, McCashland T, Befeler AS, Harnois D, Jorgensen R, Petz J, Keach J, Mooney J, Sargeant C, Braaten J, Bernard T, King D, Miceli E, Schmoll J, Hoskin T, Thapa P, Enders F. High-dose ursodeoxycholic acid for the treatment of primary sclerosing cholangitis.Hepatology. 2009;50(3):808-14.

Lindor KD. Ursodiol for primary sclerosing cholangitis. Mayo Primary Sclerosing Cholangitis-Ursodeoxycholic Acid Study Group. N Engl J Med. 1997 Mar 6;336(10):691-5.

Loftus EV Jr, Harewood GC, Loftus CG, Tremaine WJ, Harmsen WS, Zinsmeister AR, Jewell DA, Sandborn WJ.PSC-IBD: a unique form of inflammatory bowel disease associated with primary sclerosing cholangitis. Gut. 2005;54(1):91-6.

Loftus EV, Sandborn WJ, Lindor KD, La Russo NF. Interactions between chronic liver disease and inflammatory bowel disease. Inflamm Bowel Dis 1997;3:288-302.

Ludwig J, Barham SS, LaRusso NF, Elveback LR, Wiesner RH, McCall JT. Morphologic features of chronic hepatitis associated with primary sclerosing cholangitis and chronic ulcerative colitis. Hepatology. 1981;1(6):632-40.

Lundqvist K, Broomé U. Differences in colonic disease activity in patients with ulcerative colitis with and without primary sclerosing cholangitis: a case control study. Dis Colon Rectum. 1997 Apr;40(4):451-6.

MacCarty RL, LaRusso NF, May GR, Bender CE, Wiesner RH, King JE, Coffey RJ. Cholangiocarcinoma complicating primary sclerosing cholangitis: cholangiographic appearances. Radiology. 1985;156(1):43-6.

MacCarty RL, LaRusso NF, Wiesner RH, Ludwig J.Primary sclerosing cholangitis: findings on cholangiography and pancreatography. Radiology. $1983 ; 149(1): 39-44$.

MacLean AR, Lilly L, Cohen Z, O'Connor B, McLeod RS. Outcome of patients undergoing liver transplantation for primary sclerosing cholangitis. Dis Colon Rectum 2003;46:1124-1128.

Mathis KL, Dozois EJ, Larson DW, Cima RR, Sarmiento JM, Wolff BG, Heimbach JK, Pemberton JH.Ileal pouch-anal anastomosis and liver transplantation for ulcerative colitis complicated by primary sclerosing cholangitis.Br J Surg. 2008 Jul;95(7):882-6.

McGarity B, Bansi DS, Robertsson DAF, Millward-Sadler GH, Shepherd HA. Primary sclerosing cholangitis: an important and prevalent complication of Crohn's disease. Eur J Gastroenterol Hepatol 1991;3:361-364.

Mikkola K, Kiviluoto T, Riihelä M, Taavitsainen M, Järvinen HJ. Liver involvement and its course in patients operated on for ulcerative colitis. Hepatogastroenterology. 1995 Feb;42(1):68-72.

Moff SL, Kamel IR, Eustace J, Lawler LP, Kantsevoy S, Kalloo AN, Thuluvath PJ. Diagnosis of primary sclerosing cholangitis: a blinded comparative study using magnetic resonance cholangiography and endoscopic retrograde cholangiography. Gastrointest Endosc. 2006 ;64(2):219-23.

Moreno Luna LE, Gores GJ. Advances in the diagnosis of cholangiocarcinoma in patients with primary sclerosing cholangitis. Liver Transpl. 2006 ;12(11 Suppl 2):15-9.

Mulder AH, Horst G, Haagsma EB, Limburg PC, Kleibeuker JH, Kallenberg CG. Prevalence and characterization of neutrophil cytoplasmic antibodies in autoimmune liver diseases. Hepatology. 1993;17(3):411-7. 
Navaneethan U, Remzi FH, Nutter B, Fazio VW, Shen B. Risk factors for abnormal liver function tests in patients with ileal pouch-anal anastomosis for underlying inflammatory bowel disease. Am J Gastroenterol. 2009 Oct;104(10):2467-75.

Navaneethan U, Shen B.Hepatopancreatobiliary manifestations and complications associated with inflammatory bowel disease. İnflamm Bowel Dis 2010;16:1598-1619.

Olerup O, Olsson R, Hultcrantz R, Broome U. HLA-DR and HLA-DQ are not markers for rapid disease progression in primary sclerosing cholangitis. Gastroenterology. 1995;108(3):870-8.

Olsson R, Boberg KM, de Muckadell OS, Lindgren S, Hultcrantz R, Folvik G, Bell H, Gangsøy-Kristiansen M, Matre J, Rydning A, Wikman O, Danielsson A, SandbergGertzén H, Ung KA, Eriksson A, Lööf L, Prytz H, Marschall HU, Broomé U. Highdose ursodeoxycholic acid in primary sclerosing cholangitis: a 5 -year multicenter, randomized, controlled study. Gastroenterology. 2005 ;129(5):1464-72.

Olsson R, Danielsson A, Jarnerot G, Lindström E, Lööf L, Rolny P, Rydén BO, Tysk C, Wallerstedt S. Prevalence of primary sclerosing cholangitis in patients with ulcerative colitis. Gastroenterology. 1991 May;100(5 Pt 1):1319-23.

O'Mahony CA, Vierling JM. Etiopathogenesis of primary sclerosing cholangitis. Semin Liver Dis. 2006 Feb;26(1):3-21.

Outwater E, Kaplan MM, Bankoff MS. Lymphadenopathy in sclerosing cholangitis: pitfall in the diagnosis of malignant biliary obstruction. Gastrointest Radiol. 1992 ;17(2):157-60.

Papatheodoridis GV, Hamilton M, Mistry PK, Davidson B, Rolles K, Burroughs AK.Ulcerative colitis has an aggressive course after orthotopic liver transplantation for primary sclerosing cholangitis. Gut. 1998 Nov;43(5):639-44.

Parsi MA, Li A, Li CP, Goggins M. DNA methylation alterations in endoscopic retrograde cholangiopancreatography brush samples of patients with suspected pancreaticobiliary disease. Clin Gastroenterol Hepatol. 2008; 6(11):1270-8.

Penna C, Dozois R, Tremaine W. Sandborn W, LaRusso N, Schleck C, Ilstrup D. Pouchitis after ileal pouch-anal anastomosis for ulcerative colitis occurs with increased frequency in patients with associated primary sclerosing cholangitis. Gut. 1996 Feb;38(2):234-9.

Perdigoto R, Wiesner RH, La Russo N, Dozois R. Inflammatory bowel disease associated with primary sclerosing cholangitis: incidence, severity and relationship to liver disease. Gastroenterology 1991;100:1319-1323.

Ponsioen CY, Vrouenraets SM, Prawirodirdjo W, Rajaram R, Rauws EA, Mulder CJ, Reitsma JB, Heisterkamp SH, Tytgat GN. Natural history of primary sclerosing cholangitis and prognostic value of cholangiography in a Dutch population. Gut. 2002;51(4):562-6.

Porayko MK, Wiesner RH, LaRusso NF, Ludwig J, MacCarty RL, Steiner BL, Twomey CK, Zinsmeister AR. Patients with asymptomatic primary sclerosing cholangitis frequently have progressive disease.Gastroenterology. 1990 ;98(6):1594-602.

Poritz LS, Koltun WA. Surgical management of ulcerative colitis in the presence of primary sclerosing cholangitis.Dis Colon Rectum. 2003 Feb;46(2):173-8.

Rabinovitz M, Gavaler JS, Schade RR, Dindzans VJ, Chien MC, Van Thiel DH. Does primary sclerosing cholangitis occurring in association with inflammatory bowel disease differ from that occurring in the absence of inflammatory bowel disease? A study of sixty-six subjects.Hepatology. 1990;11(1):7-11. 
Rasmussen HH, Fallingborg JF, Mortensen PB, Vyberg M, Tage-Jensen U, Rasmussen SN. Hepatobiliary dysfunction and primary sclerosing cholangitis in patients with Crohn's disease. Scand J Gastroenterol. 1997 Jun;32(6):604-10.

Rea DJ, Heimbach JK, Rosen CB, Haddock MG, Alberts SR, Kremers WK, Gores GJ, Nagorney DM. Liver transplantation with neoadjuvant chemoradiation is more effective than resection for hilar cholangiocarcinoma.Ann Surg. 2005;242(3):451-8.

Riley TR, Schoen RE, Lee RG, Rakela J. A case series of transplant recipients who despite immunosuppression developed inflammatory bowel disease. Am J Gastroenterol 1997;92:279-82.

Rutter M, Saunders B, Wilkinson K, Rumbles S, Schofield G, Kamm M, Williams C, Price A, Talbot I, Forbes A.Severity of inflammation is a risk factor for colorectal neoplasia in ulcerative colitis.Gastroenterology. 2004 Feb;126(2):451-9.

Rutter MD, Saunders BP, Wilkinson KH, Rumbles S, Schofield G, Kamm MA, Williams CB, Price AB, Talbot IC, Forbes A. Cancer surveillance in longstanding ulcerative colitis: endoscopic appearances help predict cancer risk. Gut. 2004 Dec;53(12):1813-6.

Saarinen S, Olerup O, Broome U. Increased frequency of autoimmune disease in patients with primary sclerosing cholangitis. Am J Gastroenterol. 2000;95:3195-3199.

Saldeen K, Friman S, Olausson M, Olsson R.Follow-up after liver transplantation for primary sclerosing cholangitis: effects on survival, quality of life, and colitis.Scand J Gastroenterol. 1999 May;34(5):535-40.

Schrumpf E, Elgjo K, Fausa K, Gjone E, Kolmannskog F, Ritland S. Sclerosing cholangitis in ulcerative colitis. Scand J Gastroenterol 1980;15:689-97.

Shen B, Bennett AE, Navaneethan U, Lian L, Shao Z, Kiran RP, Fazio VW, Remzi FH. Primary sclerosing cholangitis is associated with endoscopic and histologic inflammation of the distal afferent limb in patients with ileal pouch-anal anastomosis. Inflamm Bowel Dis. 2010 Dec 27. [Epub ahead of print]

Shepherd HA, Selby WS, Chapman RW, Nolan D, Barbatis C, McGee JO, Jewell DP. Ulcerative colitis and persistent liver dysfunction. $Q \quad J$ Med. 1983 Autumn;52(208):503-13.

Smith M, Loe S. Sclerosing cholangitis:review of recent case reports and associated diseases and four new cases. Am J Surg 1965;110:239-246.

Soetikno RM, Lin OS, Heidenreich PA, Young HS, Blackstone MO. Increased risk of colorectal neoplasia in patients with primary sclerosing cholangitis and ulcerative colitis: a meta-analysis. Gastrointest Endosc. 2002 Jul;56(1):48-54.

Ståhlberg D, Veress B, Tribukait B, Broomé U. Atrophy and neoplastic transformation of the ileal pouch mucosa in patients with ulcerative colitis and primary sclerosing cholangitis: a case control study. Dis Colon Rectum. 2003 ;46(6):770-8.

Takikawa H, Manabe T. Primary sclerosing cholangitis in Japan--analysis of 192 cases. J Gastroenterol. 1997 Feb;32(1):134-7.

Talwalkar JA, Lindor KD. Primary sclerosing cholangitis. Inflamm Bowel Dis. 2005;11:62-72.

Terjung B, Spengler U, Sauerbruch T, Worman HJ. "Atypical p-ANCA" in IBD and hepatobiliary disorders react with a 50-kilodalton nuclear envelope protein of neutrophils and myeloid cell lines.Gastroenterology. 2000 Aug;119(2):310-22.

Terjung B, Spengler U. Atypical p-ANCA in PSC and AIH: a hint toward a "leaky gut"?. Clin Rev Allergy Immunol 2009;36(1):40-51. 
Terjung B, Spengler U. Role of auto-antibodies for the diagnosis of chronic cholestatic liver diseases. Clin Rev Allergy Immunol. 2005 Apr;28(2):115-33.

Textor HJ, Flacke S, Pauleit D, Keller E, Neubrand M, Terjung B, Gieseke J, Scheurlen C, Sauerbruch T, Schild HH. Three-dimensional magnetic resonance cholangiopancreatography with respiratory triggering in the diagnosis of primary sclerosing cholangitis: comparison with endoscopic retrograde cholangiography. Endoscopy. 2002;34(12):984-90.

Tischendorf JJ, Hecker H, Krüger M, Manns MP, Meier PN. Characterization, outcome, and prognosis in 273 patients with primary sclerosing cholangitis: A single center study. Am J Gastroenterol. 2007 Jan;102(1):107-14. Epub 2006 Oct 13.

Tobias R, Wright JP, Kottler RE, Bornman PC, Price SK, Hatfield A, Marks IN. Primary sclerosing cholangitis associated with inflammatory bowel disease in Cape Town, 1975 - 1981.S Afr Med J. 1983 Feb 12;63(7):229-35.

Tung BY, Emond MJ, Haggitt RC, Bronner MP, Kimmey MB, Kowdley KV, Brentnall TA.Ursodiol use is associated with lower prevalence of colonic neoplasia in patients with ulcerative colitis and primary sclerosing cholangitis. Ann Intern Med. 2001 Jan 16;134(2):89-95.

Vera A, Gunson BK, Ussatoff V, Nightingale P, Candinas D, Radley S, Mayer AD, Buckels JA, McMaster P, Neuberger J, Mirza DF. Colorectal cancer in patients with inflammatory bowel disease after liver transplantation for primary sclerosing cholangitis.Transplantation. 2003 Jun 27;75(12):1983-8.

Verdonk RC, Dijkstra G, Haagsma EB, Shostrom VK, Van den Berg AP, Kleibeuker JH, Langnas AN, Sudan DL. Inflammatory bowel disease after liver transplantation: risk factors for recurrence and de novo disease.Am J Transplant. 2006 Jun;6(6):1422-9.

Wee A, Ludwig J, Coffey RJ Jr, LaRusso NF, Wiesner RH.Hepatobiliary carcinoma associated with primary sclerosing cholangitis and chronic ulcerative colitis.Hum Pathol. 1985 Jul;16(7):719-26.

Wiesner RH, Grambsch PM, Dickson ER, Ludwig J, MacCarty RL, Hunter EB, Fleming TR, Fisher LD, Beaver SJ, LaRusso NF. Primary sclerosing cholangitis: natural history, prognostic factors and survival analysis. Hepatology. 1989;10(4):430-6.

Wiesner RH, LaRusso NF.Clinicopathologic features of the syndrome of primary sclerosing cholangitis.Gastroenterology. 1980;79(2):200-6.

Wiesner RH, Grambsch PM, Dickson ER, Ludwig J, MacCarty RL, Hunter EB, Fleming TR, Fisher LD, Beaver SJ, LaRusso NF. Primary sclerosing cholangitis: natural history, prognostic factors and survival analysis. Hepatology. 1989 Oct;10(4):430-6.

Worthington J, Cullen S, Chapman R. Immunopathogenesis of primary sclerosing cholangitis. Clin Rev Allergy Immunol. 2005;28(2):93-103. Review.

Zein CO, Lindor KD, Angulo P. Prevalence and predictors of esophageal varices in patients with primary sclerosing cholangitis.Hepatology. 2004 ;39(1):204-10.

Zins BJ, Sandborn WJ, Penna CR, Landers CJ, Targan SR, Tremaine WJ, Wiesner RH, Dozois RR. Pouchitis disease course after orthotopic liver transplantation in patients with primary sclerosing cholangitis and an ileal pouch-anal anastomosis. Am J Gastroenterol. 1995;90(12):2177-81. 


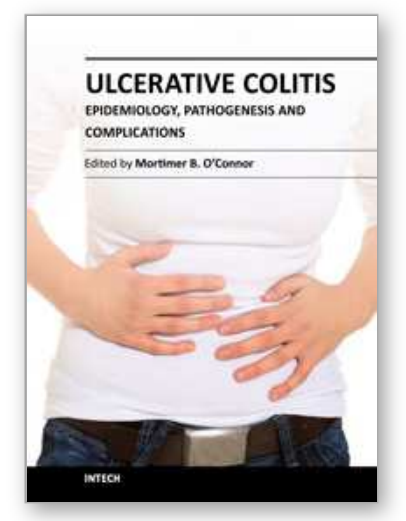

\author{
Ulcerative Colitis - Epidemiology, Pathogenesis and Complications \\ Edited by Dr Mortimer O'Connor
}

ISBN 978-953-307-880-9

Hard cover, 280 pages

Publisher InTech

Published online 14, December, 2011

Published in print edition December, 2011

This book is intended to act as an up-to-date reference point and knowledge developer for all readers interested in the area of gastroenterology and in particular, Ulcerative Colitis. All authors of the chapters are experts in their fields of publication, and deserve individual credit and praise for their contributions to the world of Ulcerative Colitis. We hope that you will find this publication informative, stimulating, and a reference point for the area of Ulcerative colitis as we move forward in our understanding of the field of medicine.

\title{
How to reference
}

In order to correctly reference this scholarly work, feel free to copy and paste the following:

Gulbanu Erkan (2011). Inflammatory Bowel Disease and Primary Sclerosing Cholangitis, Ulcerative Colitis Epidemiology, Pathogenesis and Complications, Dr Mortimer O'Connor (Ed.), ISBN: 978-953-307-880-9, InTech, Available from: http://www.intechopen.com/books/ulcerative-colitis-epidemiology-pathogenesis-andcomplications/inflammatory-bowel-disease-and-primary-sclerosing-cholangitis

\section{INTECH}

open science | open minds

\section{InTech Europe}

University Campus STeP Ri

Slavka Krautzeka 83/A

51000 Rijeka, Croatia

Phone: +385 (51) 770447

Fax: +385 (51) 686166

www.intechopen.com

\section{InTech China}

Unit 405, Office Block, Hotel Equatorial Shanghai

No.65, Yan An Road (West), Shanghai, 200040, China 中国上海市延安西路65号上海国际贵都大饭店办公楼 405 单元

Phone: +86-21-62489820

Fax: $+86-21-62489821$ 
(C) 2011 The Author(s). Licensee IntechOpen. This is an open access article distributed under the terms of the Creative Commons Attribution 3.0 License, which permits unrestricted use, distribution, and reproduction in any medium, provided the original work is properly cited. 